\title{
The process of cultural change in the Chalcolithic period in the highlands of Western Iran at Tepe Gheshlagh
}

\author{
Mahnaz Sharifi 1, Abbas Motarjem ${ }^{2}$ \\ 1 Iranian Center for Archaeological Research, Tehran, IR \\ mhsharifi588@yahoo.com \\ 2 Department of Archaeology, Bu-Ali Sina University, Hamedan, IR \\ motarjem@basu.ac.ir
}

\begin{abstract}
Tepe Gheshlagh is located in the centre of Talvar Valley in Bijar County, in the Kurdistan province of Iran, on the east bank of River Talvar. It lies on a natural terrace, less than $30 \mathrm{~m}$ above the present-day riverbed. The oval mound is about one hectare in area, and rises more than $14 \mathrm{~m}$ above the surrounding fields. Three seasons of salvage excavation carried out at the site have revealed significant information on the Early, Middle and Late Chalcolithic periods (5500-3850 BC) in this region. Unfortunately, no accurate archaeological research has been undertaken to gain a better understanding of the Chalcolithic period, especially the Early Chalcolitic, and the current excavation highlights this issue. In fact, exploration of cultural traces and, in particular, the important settlement of Tepe Gheshlagh, as well as recognition of the subsistence economy of its residents can increase our knowledge of cultural traditions in this region.
\end{abstract}

KEY WORDS - Chalcolithic period; Dalma tradition; Tepe Gheshlagh; Iranian prehistory

\section{Proces kulturne spremembe $v$ času bakrene dobe na območju zahodnega Iranskega višavja na najdišču Tepe Gheshlagh}

IZVLEČEK - Tepe Gheshlagh se nahaja na osrednjem delu doline reke Talvar (okraj Bijar, Kurdistan) $v$ Iranu, in sicer je najdišče locirano na vzhodnem bregu reke. Pozicija najdišča je na naravni terasi, ki se dviga manj kot 30 metrov nad današnjim koritom reke. Ovalna gomila zajema območje enega hektarja in se dviga 14 metrov nad okoliška polja. V treh sezonah zaščitnih izkopavanj smo pridobili pomembne informacije o zgodnji, srednji in pozni bakreni dobi (5000-3850 pr.n.št.) na tem območju. Z novejšimi izkopavanji smo osvetlili tudi čas zgodnje bakrene dobe, ki do sedaj na tem območju ni bila primerno arheološko raziskana. S pomočjo analize kulturnih ostalin in naselbine Tepe Gheshlagh ter analize subsistence takratnih prebivalcev smo povečali naše vedenje o kulturni tradiciji v regiji.

KLJUČNE BESEDE - bakrena doba; tradicija Dalma lončenine; Tepe Gheshlagh; prazgodovina v Iranu

\section{Introduction}

The Chalcolithic period in the central Zagros, starting at $c .5500 \mathrm{BC}$ and lasting until $3000 \mathrm{BC}$, marks one of the most important prehistoric periods in Iran, with quite different characteristics compared to the Neolithic period. The chronological sequence is based on thermoluminiscence dating. The local rural communities and their settlements established in the Neolithic period were developed significantly. Tepe Gheshlagh is one of such settlement.

The Chalcolithic period in different parts of the Iranian plateau is difficult to study because of the lack 
of absolute ${ }^{14} \mathrm{C}$ dates, so it cannot be easily distinguished from the Neolithic. In most of the research carried out so far, the only difference between these periods is in the pottery types, which certainly cannot be the only reliable source for distinguishing between one period and another, although it seems to be a significant feature. We may mention here the work of Elizabeth Henrickson, Cuyler Young, and Louis Levin on the west of Iran (Henrickson 1983; 1985; Young, Levine 1974). The second reason is the absence of integrated and comprehensive research in this area after the Islamic Revolution in Iran. Certainly, no systematic research was done in western Iran during these years, which could have examined a considerably important settlement of the Chalcolithic period, and present a cohesive and related introduction to its cultural material, rather than some unrelated examples. Hence, comprehensive research of the Early, Middle and Late Chalcolithic periods in Gheshlagh Region is needed. Unfortunately, inconsistent approaches in earlier excavations have led to presentations of fragmentary results, so that it is still impossible to answer many questions concerning the mutual interactions between different areas in the Chalcolithic period. The third reason is that in this period, a larger area of the western highlands of Central Zagros was inhabited, while there had been no reports of any earlier settlements in these regions (Levine, McDonald 1977). On the other hand, according to the preliminary results of some field studies, there was a relative increase in the population of these areas, mainly due to movements from surrounding areas due to factors such as population increase (Motarjem 2011). The same premise applies to the material found in a number of excavations, and shows the similarity of

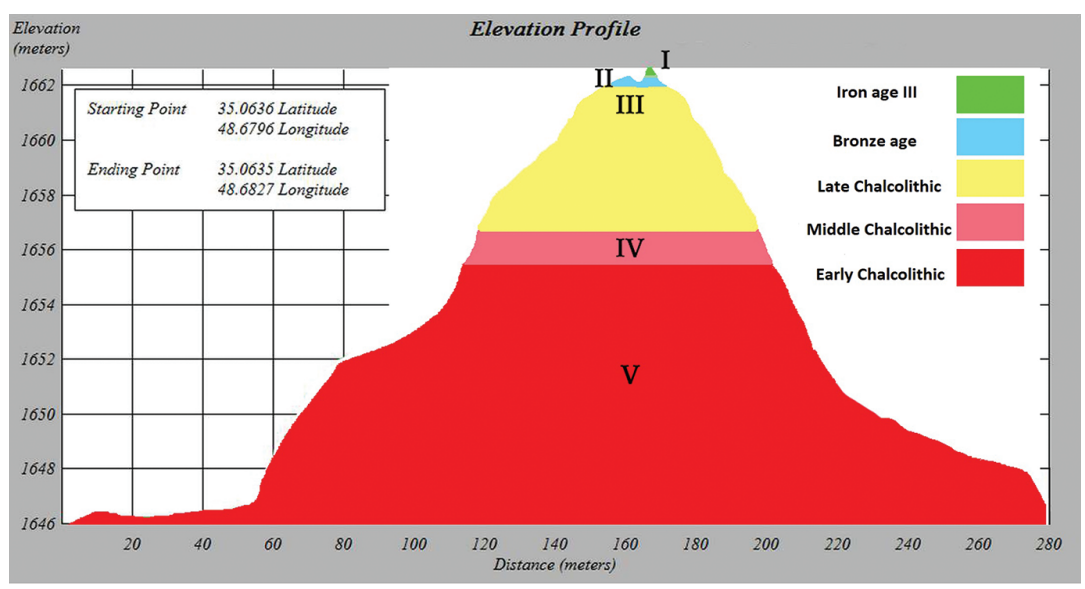

Fig. 2. Tepe Gheshlagh - section profile. view of Gheshlagh

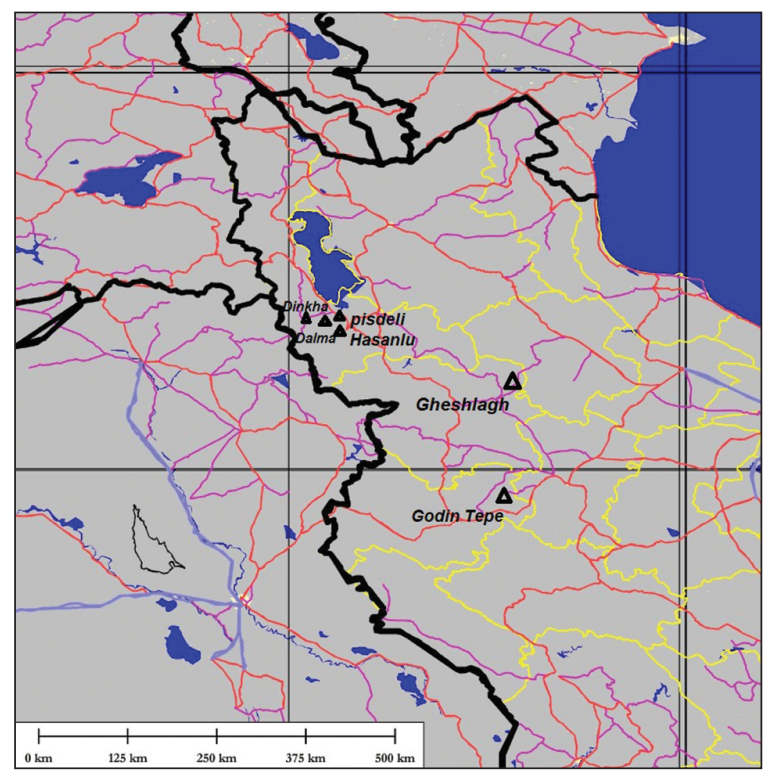

Fig. 1. The location of Tepe Gheshlagh in western Iran.

pottery styles over a wide geographical area. Furthermore, environmental and climatic differences in different parts of Zagros, ranging from the north to the west of Iran, had a great influence on the uneven development of these cultures. In other words, there are marked environmental-regional differences in almost all the cultures related to the Chalcolithic period.

One of the most important Chalcolithic cultures in northwest and north Iran is known as the 'Dalma pottery tradition'. Our information on this tradition is limited. It is known at Tepe Dalma (Hamlin 1975), as the second-earliest culture around Lake Uremia after the Hajji Firuz Phase (Voigt 1983). Diversity and differences in some special cultural elements relate to social and economic changes, as well as to cultural adaptation to stable environments in the region. They include variations in the material culture, found in three southern sites (at Lake Uremia, Talvar Valley, and Central Zagros) as subcategories of the Dalma tradition. The cultural scope of Dalma has been recognised through archaeological excavations not only in the southern basin of Lake Uremia, but also in vast areas stretching from northwest Mesopotamia to northern Anatolia, as well as from north and 
northwest Iran to the natural boundaries of Jebel Hamrin and on the periphery of Khuzestan plain. This shows the cultural evolution and adaptation to environment, since each region demonstrates some specific regional differences along with the general characteristics.

Assessing the relative and absolute chronology of the region in order to identify the precise dates of settlements as well as cultural layers is the main focus of this paper. We also focus on cultural communication between settlements along the eastern ranges of central Zagros and the nearby areas in northwest Iran and Mesopotamia, as well as on the origins and formations of early cultures and their transformation into more complex subsistence and social systems. How much did the environment, climate changes, and neighbouring cultures influence the cultural components of the Chalcolithic period? Were cultural changes in the Talvar Valley due to local transformations or the influence of surrounding areas? What were the cultural interactions between the local residents and the neighboring areas; were they more influenced by the northwest culture (Dalma), or the cultural phases of central Zagros?

\section{Archaeological background}

No systematic archaeological studies were carried out in Bijar Province before 1971, when Stuart Swiny carried out archaeological research on the main plains of the southern basin from the northwest to the borders of central Zagros in Hamadan. He identified Dalma sites in the highlands of Kurdistan across the southern basin of Uremia Lake and Bijar Province (Swiny 1975). We can also mention the archaeological excavations in Tepe Rezaabad (Mohamadifar 2010) as well as Tepe Gheshlagh in 1991, 1992, and 1993, which continued until they reached the archaeologically sterile layer (Motarjem 2011;
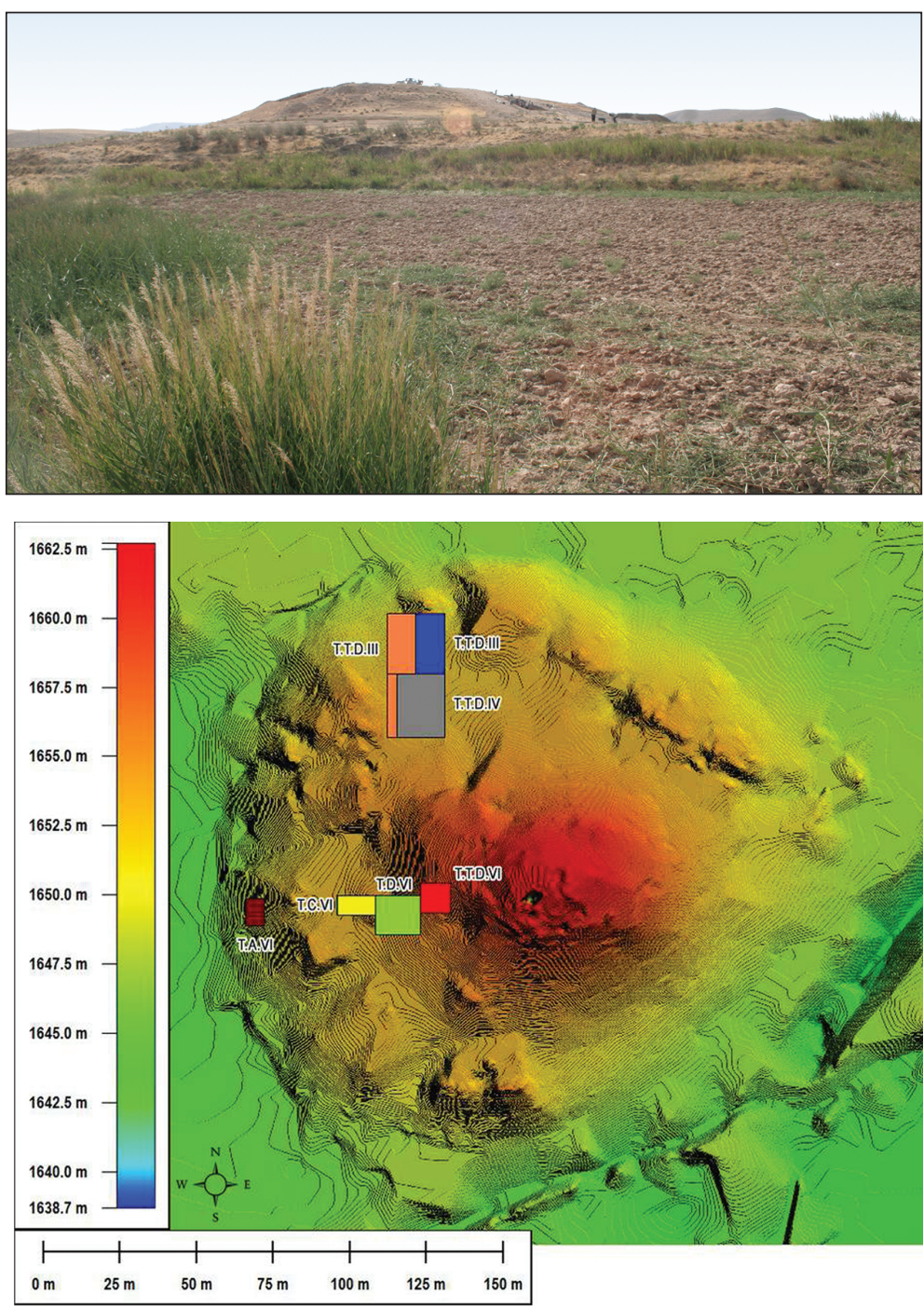

Fig. 3. General view of Tepe Gheshlagh (above) and topographic map showing the location of trenches (down).

Motarjem, Sharifi 2014; 2015). The excavation of Tepe Kolnan (Saed 2010) is among the research projects conducted in Bijar. In 2009, a continuous sequence from the Middle Palaeolithic up to the Bronze Age was documented and published (Mohammadifar, Motarjem 2009). The Chalcolithic oc-

\begin{tabular}{|c|c|c|c|c|c|}
\hline & Phase & Depth & $\begin{array}{l}\text { Cultural } \\
\text { Phases }\end{array}$ & $\begin{array}{l}\text { Date } \\
\text { (BC) }\end{array}$ & $\begin{array}{l}\text { Regional } \\
\text { Tradition }\end{array}$ \\
\hline 1 & III & $-5.38 \mathrm{~cm}$ & Late Chalcolithic & $\begin{array}{c}3600 \pm 220 \\
3800\end{array}$ & GODIN VII \\
\hline 2 & III & $-6.84 \mathrm{~cm}$ & Late Chalcolithic & $3915 \pm 270$ & GODIN VII \\
\hline 3 & III & $-7.60 \mathrm{~cm}$ & Late Chalcolithic & $\begin{array}{c}3850 \pm 280 \\
4100\end{array}$ & GODIN VII \\
\hline 4 & & & & $\begin{array}{c}3960 \pm 290 \\
4100\end{array}$ & \\
\hline & $\mathrm{V}$ & $-12.50 \mathrm{~cm}$ & Early Chalcolithic & $5000 \pm 305$ & Dalma tradition \\
\hline 6 & $\bar{V}$ & $-14 \mathrm{~cm}$ & Early Chalcolithic & $5500 \pm 250$ & Dalma tradition \\
\hline
\end{tabular}

Fig. 4. Chronological table of Tepe Gheshlagh, based on thermoluminescence dating. 

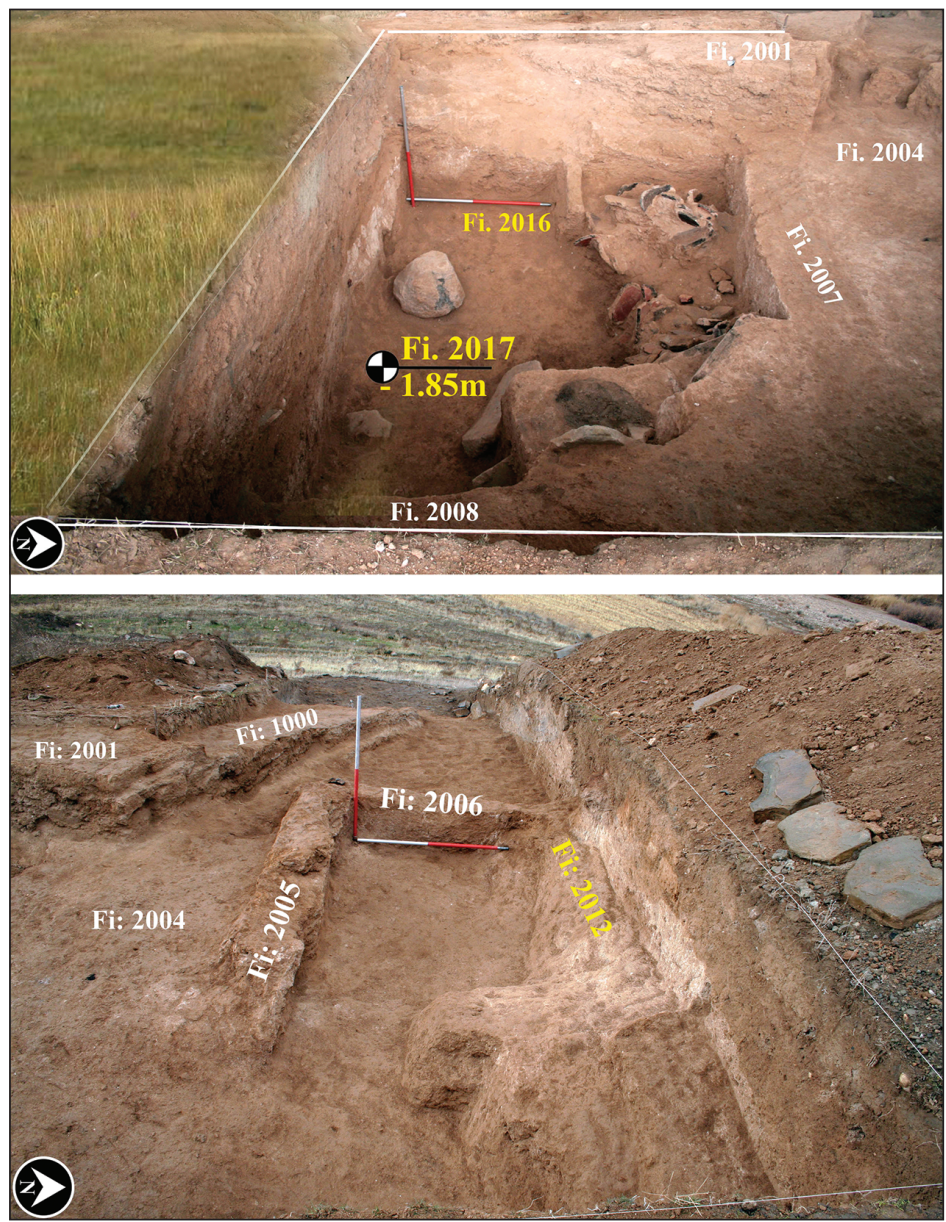

Fig. 5. Phase I - the Late Chalcolithic period in layer 3 at Tepe Gheshlagh.

cupations in the east of central Zagros were documented by excavations in Tepe Seh Gabi and Godin (Young 1969; 1975; McDonald 1979.348; Levin, Young 1986.17; Henrickson 1983.478; 1985.60). Research in Chogha Maran and Siahbid in the west of central Zagros in Mahidasht revealed Late Chalcolithic pottery, which is known as ' $\mathrm{J}$ Ware' (Levine, Mc Donald 1977.44). 'J Ware' originated from Mesopotamia (the Late Halaf period), and hence was made using similar technology; and in terms of fabrics and forms, it resembles the pottery of the Late $\mathrm{Ha}$ laf period (Levin, Young 1986.1921; Henrickson 1983.80; 1985.69; Levine, McDonald 1977; Rothman, Badler 2011.75).

Some Dalma ceramics were found during surveys in Mahidasht, and at two excavated sites, Chogha maran and Siahbid (Henrickson, Vitali 1987.38). At the Godin site, phase VIII is known as the Taherabad phase, which is attributed to the end of the mid-Chalcolithic period (Henrickson 1985). The late Chalcolithic period is recognised through pottery from Godin phases VI-VII, which is concurrent with the Hosseinabad phase and Cheshme Nosh in Segabi (Henrickson 1985.74). At Godin Tepe, traces of phase VII-VI were found in trenches A, E, and F (Young, Levine 1974. 12). Cuyler T. Young and Elizabeth F. Henrickson (1991.281) believe there are significant traces of cultural continuity of Godin VII that most probably began in the mid-Chalcolithic phase III. The analysis of plant remains revealed traces of wheat and barley in the Godin excavations (Miller 2011.59). The archaeological excavations of the Chalcolithic period in Ghazvin plain in the central plateau of Iran were carried out by Hassan Fazeli and Mark Pollard (see Pollard et al. 2012; Fazeli et al. 2013).

\section{Tepe Gheshlagh}

The mound measures about $80 \mathrm{~m}$ long and $70 \mathrm{~m}$ wide, covering a total area of approx. $5600 \mathrm{~m}^{2}$. At the highest point, it rises about $7 \mathrm{~m}$ above the surrounding land. It is the largest prehistoric site in the Talvar Valley (Fig. 2). During three seasons of excavations (Motarjem Sharifi 2015.27), five cultural layers were identified at Gheshlagh, showing the cultural continuity from the Early Chalcolithic to the Iron Age III period, along with two culture gaps that will be presented below (Fig. 3).

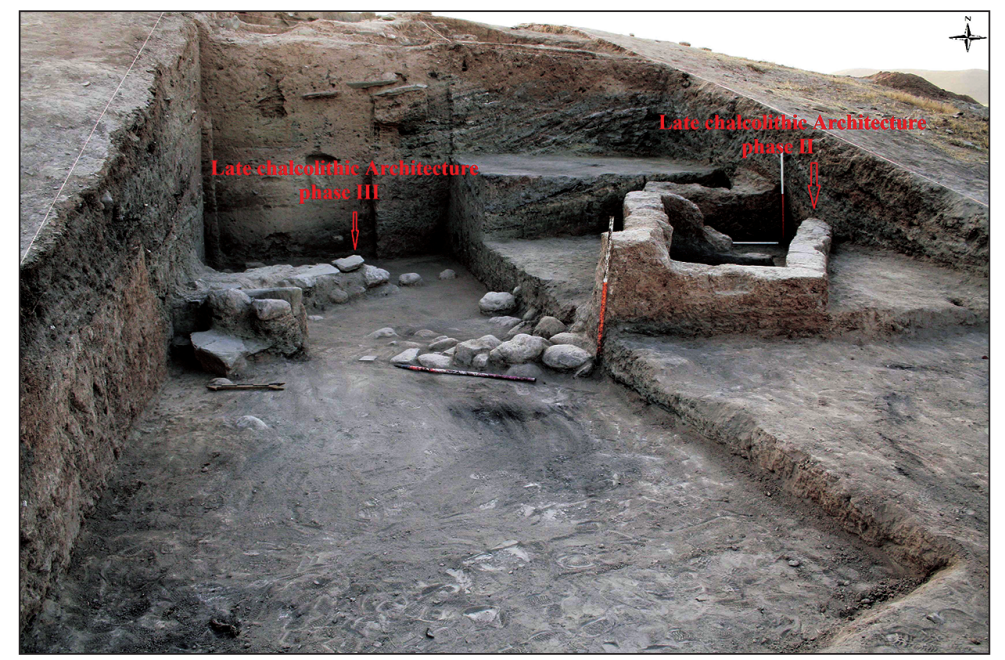

Fig. 6. Phase II - the Late Chalcolithic period in layer 2 at the site. 
- Layer 1: the Iron Age III layer with architectural remains in the right corner that include mudbrick walls with stone foundations. The cultural remains include pottery and a child burial in a trench.

- Layer 2: the cultural layer of this level is $60 \mathrm{~cm}$ thick and, according to archaeological studies, dates to the Late Bronze Age.

- Culture hiatus II: this gap falls between the Early and Middle Bronze ages and the Late Chalcolithic period. In terms of chronology, it is synchronous with Godin VI phase, and
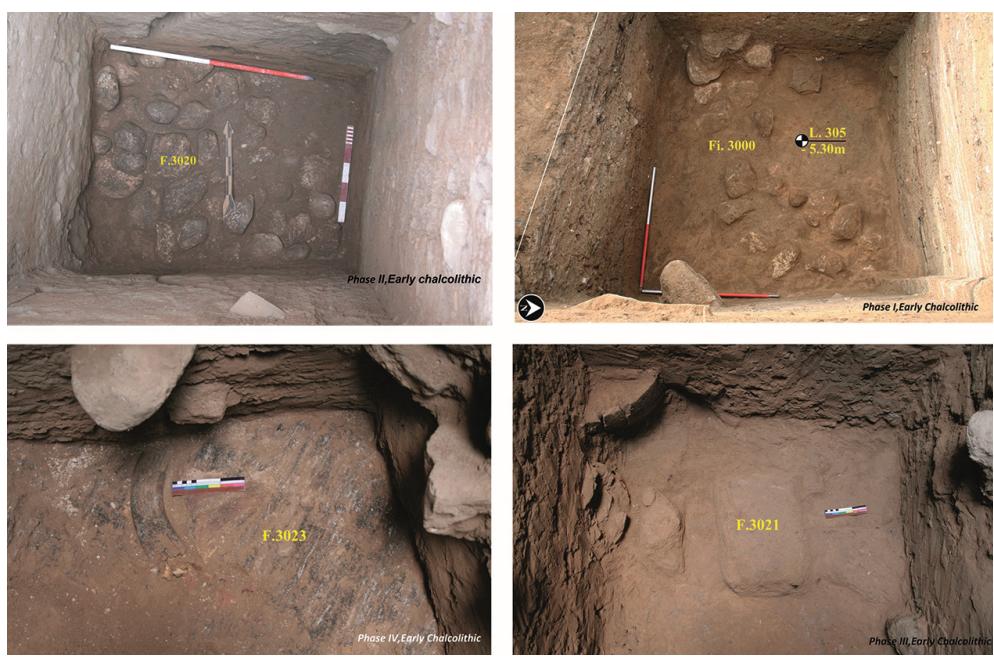

Fig. 7. Phases I to IV - the Early Chalcolithic period at the site.

then with the cultural development of Kura-Araxes or Yanik in the northwest and eastern parts of central Zagros, which dates to 1600-2800 BC. Most of the ${ }^{14} \mathrm{C}$ dates and relative chronology indicate that the Kura-Arex culture emerged in central Zagors around $3000 \mathrm{BC}$. In view of the special developments and migration in this period, the region appears to have been empty of population, while the same culture in the Talvar Valley has been identified in a field survey. The cultural hiatus is an indication of the relocation of settlements and the consequence of differences in subsistence. The Talvar plain was not inhabited, but the patterns of establishment changed.

- Layer 3: the Late Chalcolithic layer includes three architectural phases (about $5 \mathrm{~m}$ thick). In Phase I, we found a complete building plan in the top layer that included a room, a hall, and a separate rectangular kitchen space made of mud brick, as well as an outer wall (Fig. 5). Thermoluminescence dating determined the relative and absolute dating of this layer to the Late Chalcolithic period, with three separate phases $(3915 \pm 270,3850 \pm 280,3600 \pm 220 \mathrm{BC})$. The archaeological finds follow traditions in central Zagros (Motarjem, Sharifi 2014.49). An oven and a mud brick structure were discovered in the Late Chalcolithic phase II, and phase III included stone structures (Fig. 6).

- Layer 4: the Middle Chalcolithic layer is $0.55 \mathrm{~m}$ thick and lackisany type of architecture; it was identified by its cultural remains. The pottery includes Pizdeli, Seh gabi, Black-on-Buff and Red-on-Buff pottery, which indicate some cultural connections between this area and the Lake Uremia basin, as well as with the east of central Zagros (Henrickson 1983. 246; Levin, Young 1986. Fig 17:36, No. 9). Since the pottery resembles Pizdeli and Seh Gabi types, and also based on comparisons with the Lake Urmia basin material, this phase is recognised as the Hasanlu VIII and Godin IX phases. The deposits from this area date to the Middle Chalcolithic period (Motarjem, Sharifi 2014.52).

Layer 5: the cultural characteristics of this 5-metrethick layer date to the Early Chalcolithic period or

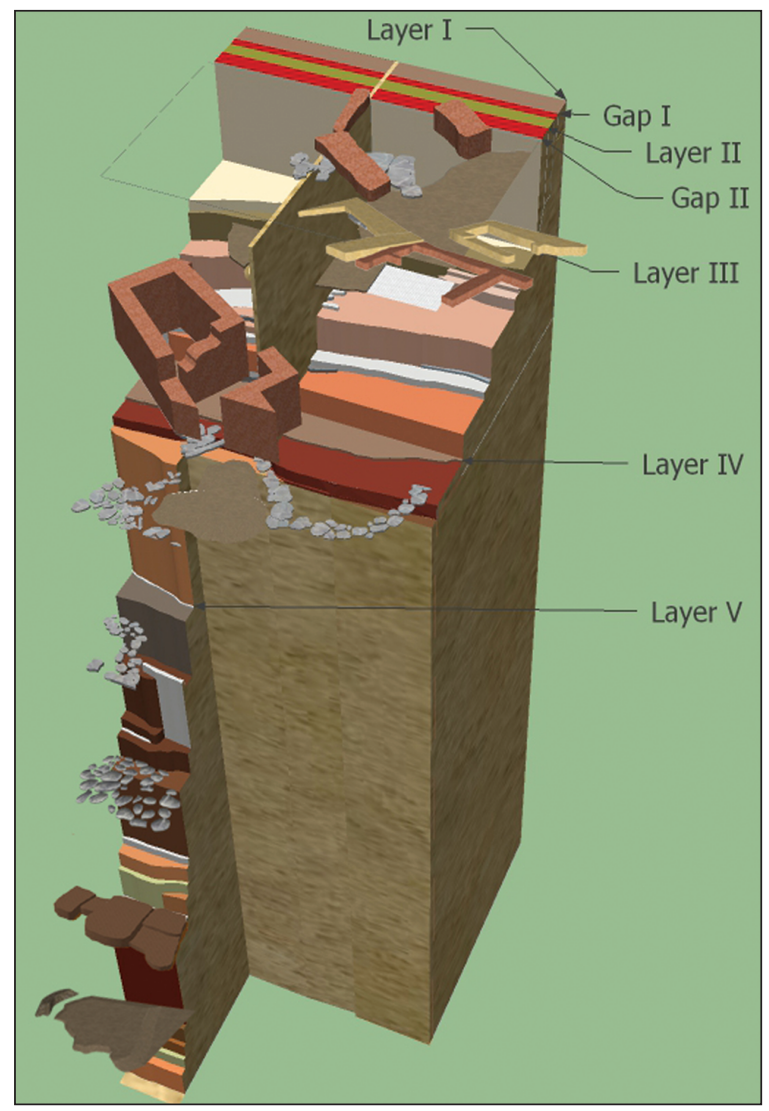

Fig. 8. A reconstruction of the spatial sequence of architecture at the site. 


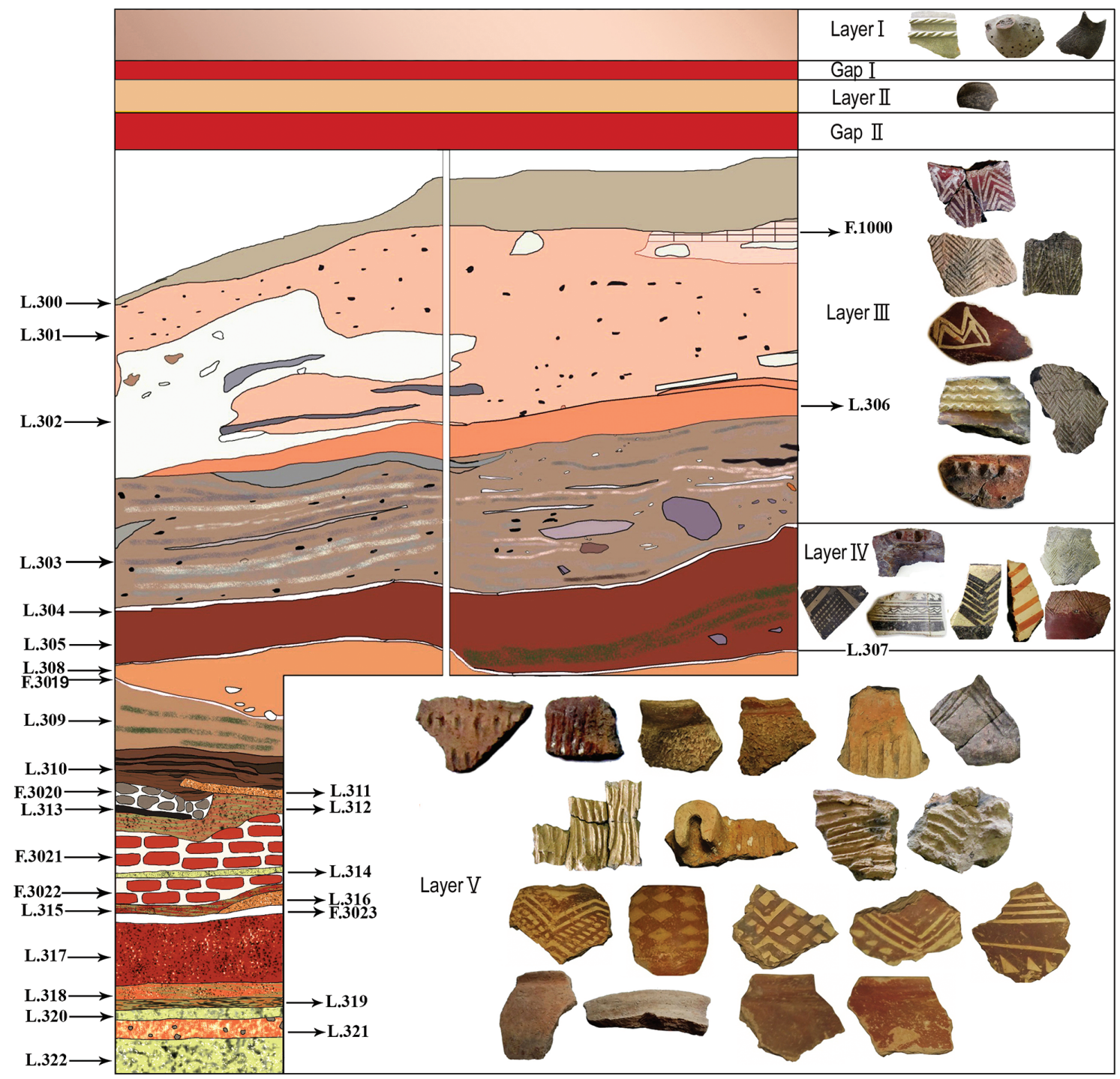

Fig. 9. Stratigraphic section of trenches II and III at the site.

Dalma phase. Four occupational phases were identified in this level, and the comparisons, especially for the Dalma ware, show connections with the Early Chalcolithic period in the south of Lake Urmia. The first phase includes crushed dry stone, as well as husking trays. The second phase contained the remains of stone constructions made of gypsum. The remains of moulded mud brick structures were found in the third phase. Phase IV contains the last trace of the Early Chalcolithic period, with a residue of reed and sedge on a beaten floor (Fig. 7).

\section{Material culture at Tepe Gheshlagh}

The Tepe Gheshlagh layer III pottery can be divided into several groups: open bowls with incurving rim and a handle, incurving rim bowls without handles, bowls with inverted rim, cups, decorated storage jars, and small bowls. Different types of streaky de- corated storage jars were found in this area. These wares are dated to the Middle and Late Chalcolithic periods, and belong to the characteristic pottery type of the east of central Zagros, the Dalma phase or Godin X, also known as Dalma streaky pottery (Henrickson 1983). They reveal close technical connections with the incised pottery of lower Hassuna (Lloyd, Fuad Safar 1945.Fig. 10; Braidwood et al. 1983). A few pieces of Tepe Gheshlagh pottery had decorations on the vessel bases.

Based on decoration, the pottery in layer III is divided into two categories: plain and painted ware. Plain pottery was made with two types of slip - also reported in Seh Gabi and Godin VII (Young, Levine 1974) - as well as without a slip.

The pottery with a slip at Tepe Gheshlagh is up to $80 \%$ covered with a thick slip, and the firing is large- 

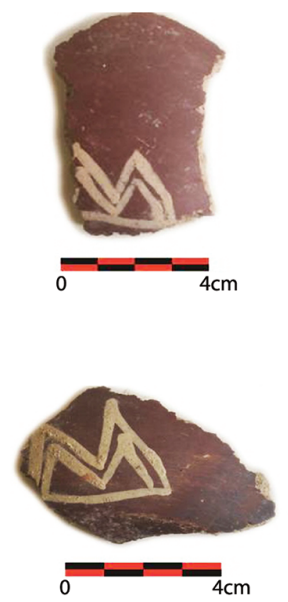
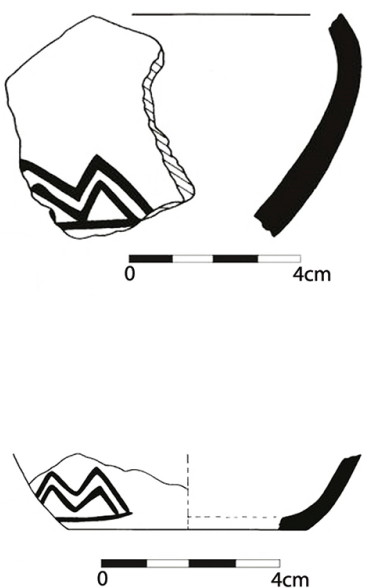
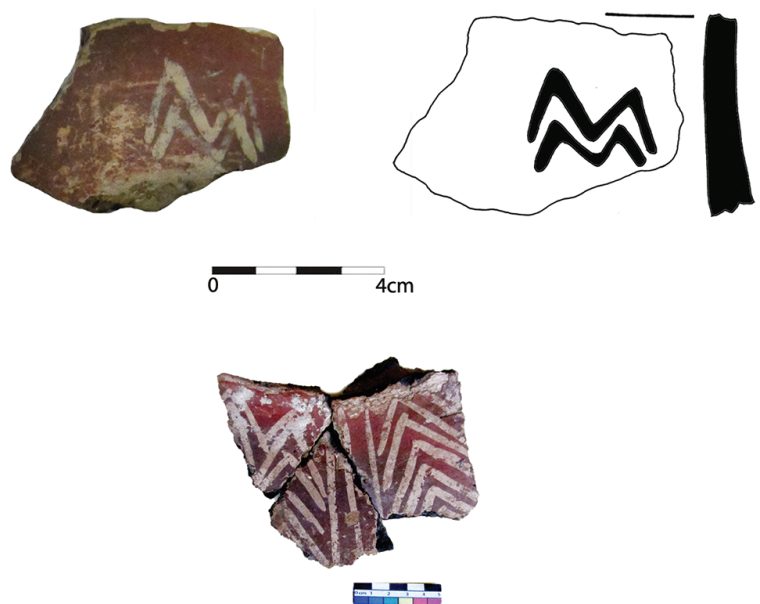

Fig. 10. The Late Chalcolithic pottery from Tepe Gheshlagh.

ly insufficient. There are two main reasons for the poor firing of the pottery: the energy required to reach the optimum temperature for perfect firing was not available, or the temperature was high enough, but the firing was too brief. These reasons could be due to a lack of facilities and stable environmental conditions, as well as pottery technology. Climatic conditions and limited access to energy resources could be the main reason for the firing conditions, since no significant climate changes have been reported for the area after the Chalcolithic period. We propose that this situation was similar to the pre-history situation, with only slight differences (Heidari 2016).

The plain, un-slipped pottery includes two sherds of lentil-shaped wares, and a short rimmed vessel, and
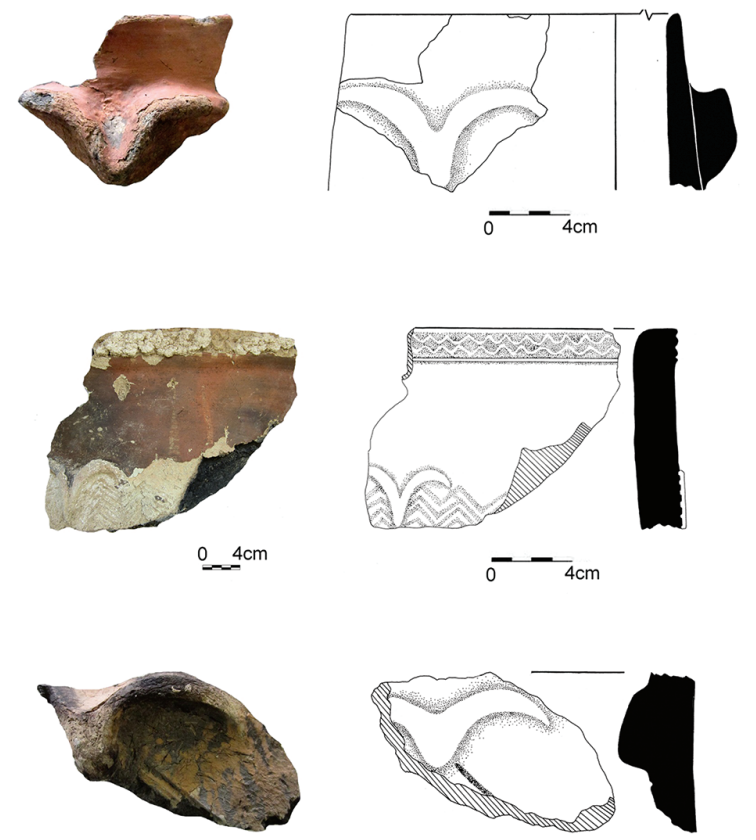

according to topographic tests, they did not originate in this area, and were probably imported from Mesopotamia.

Painted pottery is divided into several classes, including geometric patterns, animal motifs, natural elements, and Halaf slipped pottery decorations, applied decorations, and incised designs.

The geometric patterns in layer III that were abundantly obtained from the Late Chalcolithic period comprise repeated zigzag motifs in white on a brown background; similar pieces were found in Haji-firuz and Sarab (Levine, McDonald 1977.40). Similarities between the pottery from Tepe Gheshlagh and the geometric designs of the Neolithic period in Sarab, Hassuna in Iraq, and Haji-firuz in Azerbaijan indicate
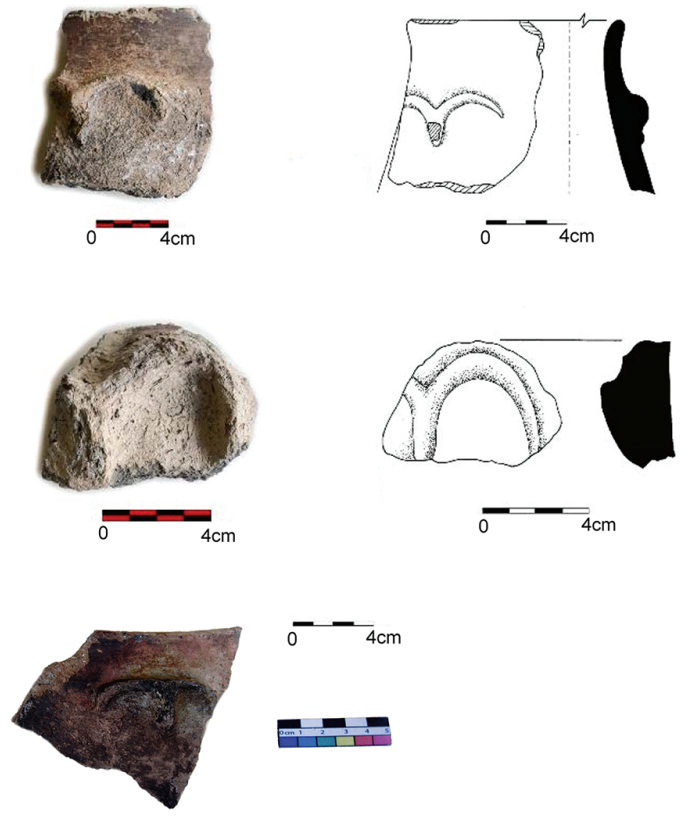

Fig. 11. Pottery samples with applied decorations from Tepe Gheshlagh. 

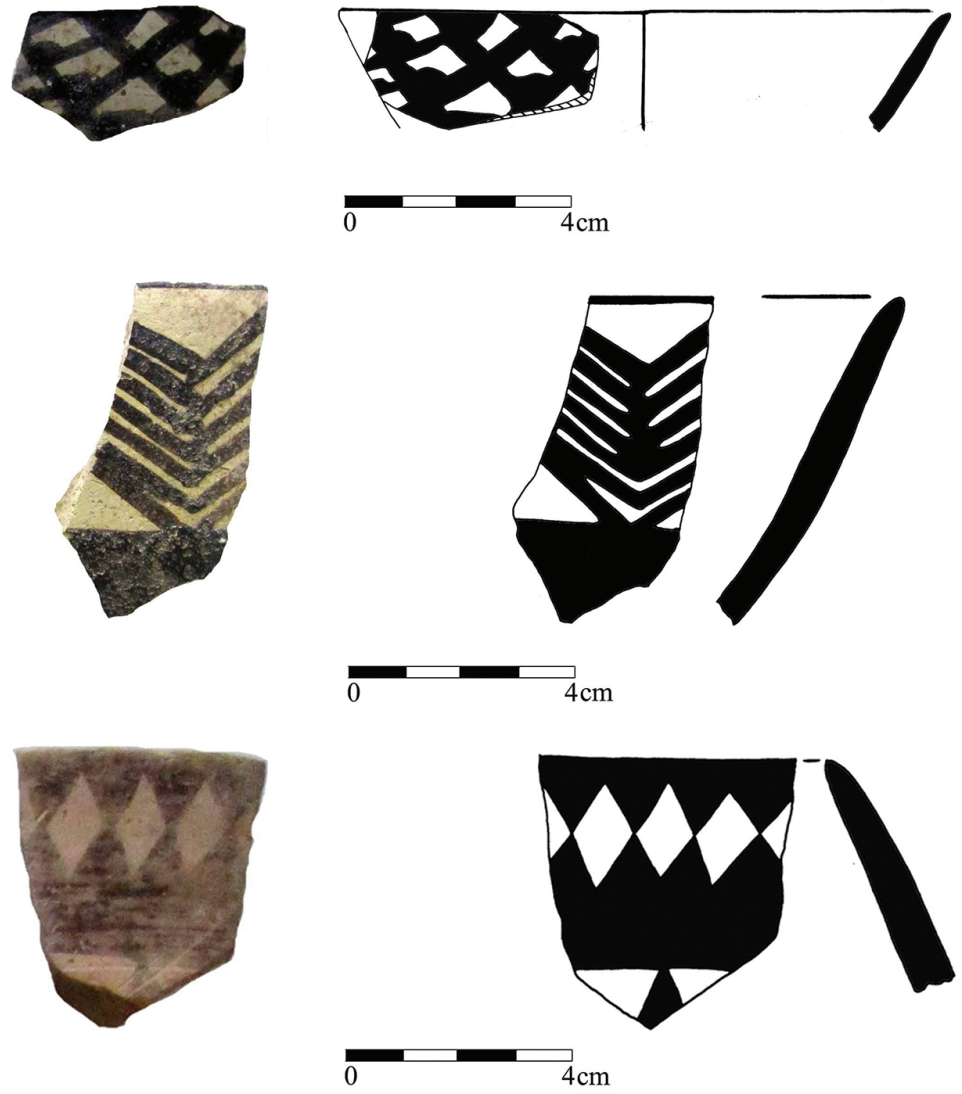

Fig. 12. Middle Chalcolithic pottery from layer IV at the site.

designs (Fig. 17), and special handles with striated decorations. Impress and streaky pottery generally date to the Early Chalcolithic period found in phase I, in layer $\mathrm{V}$ at the site. This type of pottery has been found in abundance outside the borders of Iran. Semi-husking trays were discovered in phase II which are reminiscent of Hassuna types. The distribution of this type of pottery in other areas suggests its widespread popularity.

Similar ornamental traditions were reported in the north of Iraq and in Turkey (Yildrim, Gates 2007.283), at Gil Stein's excavations (Stein 1998) in Hajinabi, South Anatlia and Hakemi Use (Tekin 2007), and in Tepe Haji-firuz (Voigt 1983.101102). This phase must be transitional from the Hassuna to Dalma culture. This type of pottery seems to be kitchenware. Incised streaky decorations were local features in Tepe Gheshlagh during the Early, Middle,

the continuity of cultural traditions which continued also in the next periods (Fig. 10).

Applied decorations include some animal horns; the most dominant motifs are rams' and goats' heads, wholly abstracted and summarised. This technique of pottery decoration is also found on pottery types from the lower Hassuna period in Umm Dabaghiyah (Fig. 11).

Rope ornamentation was abundant in layer III, as well as in the Late Chalcolithic III period. This design was found in a single-row form on the Central Plateau, at Tepe Ghabristan, while a three-row design was recoded at Tepe Gheshlagh. This decoration technique was an innovation by the Tepe Gheshlagh potters, as the design is unique to this site (Fig. 15).

Appliqué handles, known as Godin VII pottery, were found in abundance in layer III, as well as in all the other phases.

Incised decoration on pottery most commonly comprises incised chevrons under the rim, which is obliquely decorated. Incised designs in layer $\mathrm{V}$ (the Early Chalcolithic period) include four types: streaky pottery (Fig. 14), husking trays (Fig. 16), impressed and Late Chalcolithic periods.

The Dalma style painted pottery includes geometric designs characteristic of the Early Chalcolithic pottery (Fig. 18). The designs include geometric patterns, diagonal, vertical, and horizontal lines, intersecting, zigzags, separate and diamond shaped, as well as small triangles and rectangles, which were used extensively in Dalma, Godin, and Seh Gabi pottery. The Late Chalcolithic Tepe Gheshlagh pottery was greatly influenced by the Azerbayian style, especially Dalma and Haji-firuz. It is technically similar to the Neolithic pottery in Haji-firuz, as well as the tadpole pottery of the Middle and Late Neolithic in Zagros, which has been reported from many sites (Merpert, Munchaev 1973.Plate XLI.2).

\section{Discussion and conclusion}

In general, the pottery tradition found in layers III, IV, and $\mathrm{V}$ at Tepe Gheshlagh includes storage jars with streaky decorations and a thick red slip, which is a local tradition at this site from the oldest layer $\mathrm{V}$ to layer III. There are also obvious similarities between the pottery tradition in layer III at Tepe Gheshlagh and Godin VII phase, which indicates their connections. Moreover, at least two other pottery 
types occur, i.e. Ubaid or Susiana, which, based on colour, form and fabric (also suggested in petrographic studies), differ from the other pottery in Tepe Gheshlagh, indicating relations with other areas. Thermoluminescence dating carried out on two pottery fragments, deposited in layer III suggest dates of $3850 \pm$ 280 and $3600 \pm 220 \mathrm{BC}$. Ba-

sed on the material and all the analyses, as well as the relative and absolute chronology, this layer can be dated to the Late Chalcolithic period. Additionally in layer III at Tepe Gheshlagh, we can observe a connection or interaction between Pisdeli pottery traditions from the south of Lake Uremia and the painted pottery tradition of Seh Gabi, which proves that both areas were influenced by these two traditions. The absolute chronology of these two phases of layer III is $3915 \pm 270 \mathrm{BC}$ and $3960 \pm 290 \mathrm{BC}$.

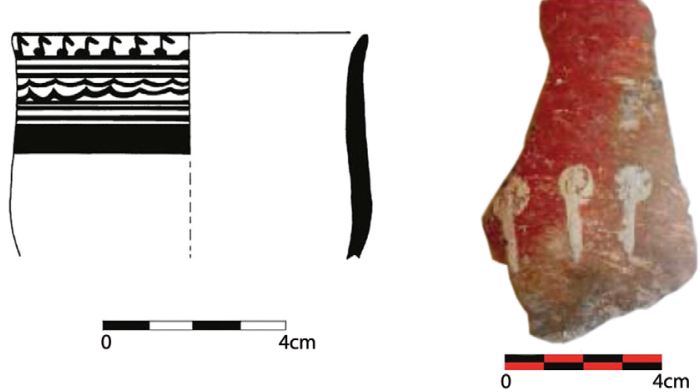

Fig. 13. Early Chalcolithic pottery at Tepe Gheshlagh.

sin of Lake Urmia, and see how this tradition penetrated through central Zagros in the lowest depositions of Tepe Seh Gabi; and during the Godin VII phase, this tradition most probably encompassed the entire area of Zagros.

In general, the small and narrow valley of the Talvar is like a natural corridor, which makes possible communication between residents of eastern areas of Central Zagros with the south of Lake Urmia. This
The continuity of the pottery tradition during the long period of layer $\mathrm{V}$ (Early Chalcolithic) is explained as follows:

- Layer I - prevalence of Impressed Dalma pottery;

- Layer II - prevalence of Hassuna sherds, including geometric semihusking trays and Haji firuz pottery;

- Layer III - pottery with horned handles, and their continuity into other periods or the same layers of III and IV, under the influence of the Umm Dabaghiyah culture;

- Layer IV - this layer, which is approx. $9.5 \mathrm{~m}$ thick, definitely belongs to the Dalma period; the absolute chronology in the lowest layers indicates date of $5500 \pm 250$ BC.

Given the presence of the Dalma tradition, including painted, impressed semi-husking trays, and streaky pottery in a layer $9 \mathrm{~m}$ thick, and due to their date at $5500 \mathrm{BC}$, these finds must be local to this area, and not influenced by any other areas. We can observe the important influence of Dalma pottery from the southern ba-
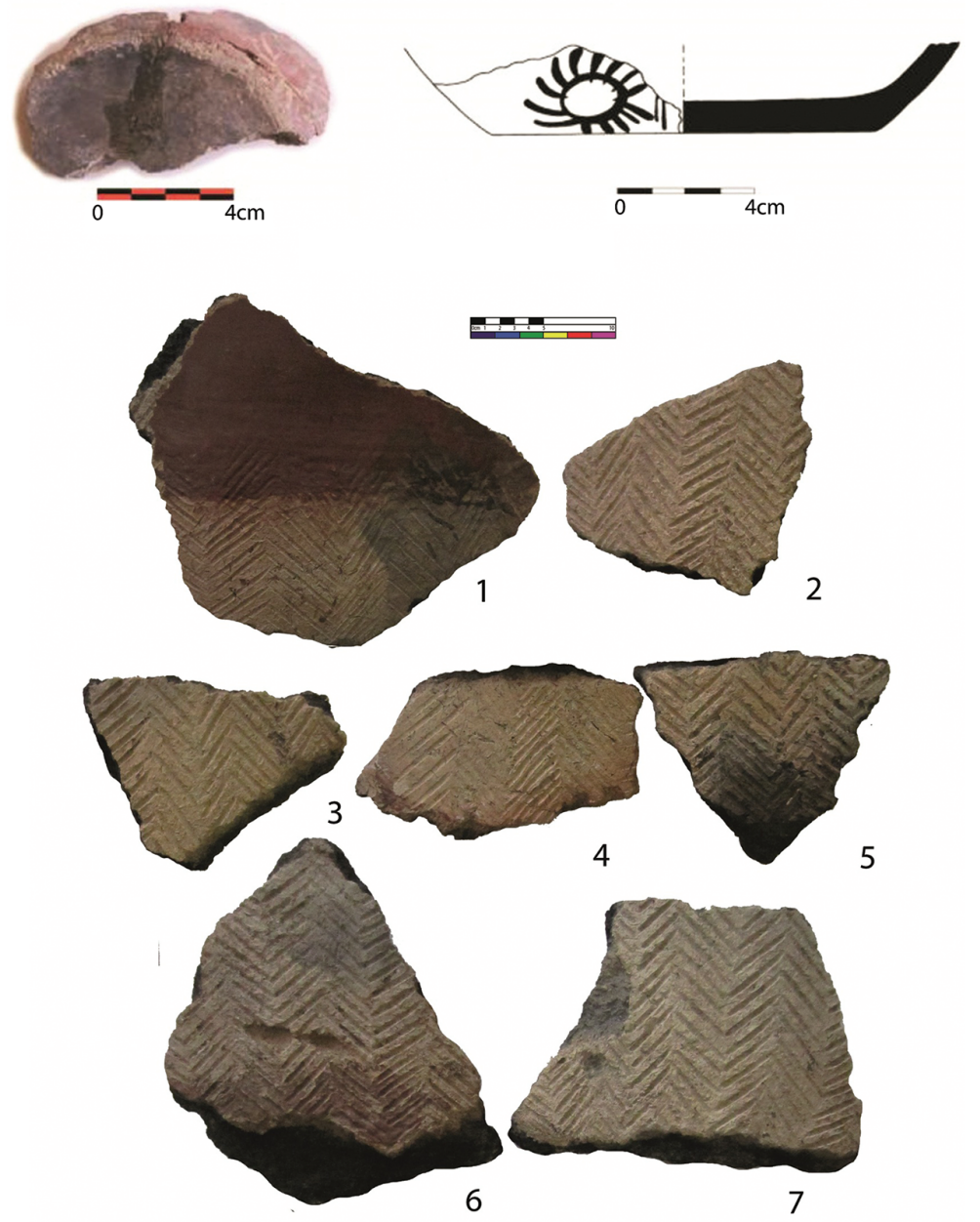

Fig. 14. Incised chevron decorations seen on streaky pottery at Tepe Gheshlagh. 

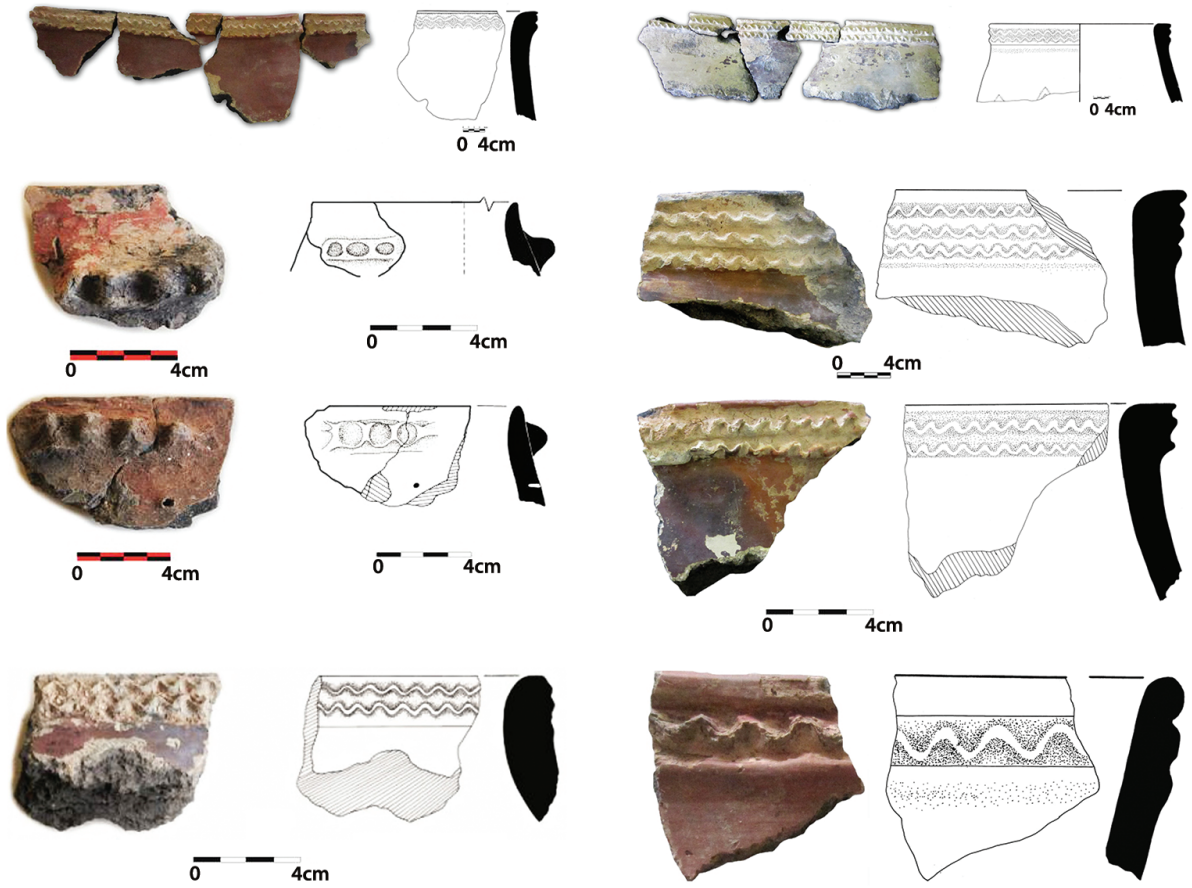

$\sigma^{-}{ }_{4 \mathrm{~cm}}$

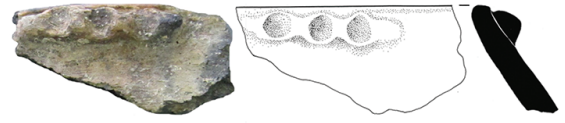

$-{ }^{-} \mathrm{cm}$

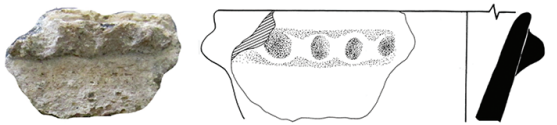

$-{ }^{-}{ }_{4 \mathrm{~cm}}$

Fig. 15. Rope ornament and Godin VII pottery at Tepe Gheshlagh.

route includes a series of connected valleys. Regarding its elevation, over $1600 \mathrm{~m}$ a.s.l., its semi-steppe vegetation makes it unsuitable for cultivation. However, these conditions provide good pastures, and a natural habitat for animals such as goats, sheep, rabbits and pigs. These features, along with the permanent water supply of the River Talvar, made for suitable settlement conditions throughout the Chalcolitic period. The mode of production combined hunting and animal husbandry, while fishing also had a significant role.

The presence of Ubaid pottery and obsidian artefacts, prove the existence of trans-regional connections. Also, the great prevalence of tokens and their diversity indicates the existence of an open economic system in conntact with neighbouring areas. The widespread use of stamp seals in particular in this area is regarded as evidence of the existence of such a

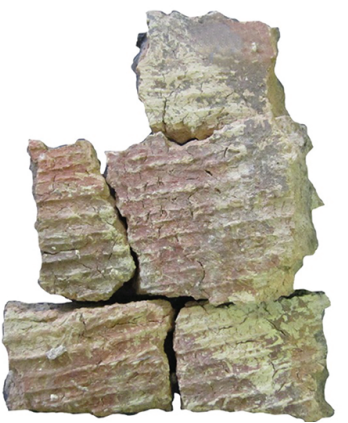

system. Moreover, one thousand years of uninterrupted occupation in this region was a result of the relatively stable climate and environment, which changed only at the end of the Late Chalcolithic, and then in the Godin VII phase, as Yanik-related peoples entered into the region and changed the spatial site arrangement. Most Chalcolithic sites were abandoned in this period, and new settlements were founded at the foot of a mountain.

Most archaeological finds come from the thick deposition of the Early Chalcolithic layer V at Tepe Gheshlagh, which is dated to the Dalma pottery tradition. Only a few changes occurred in this layer, but
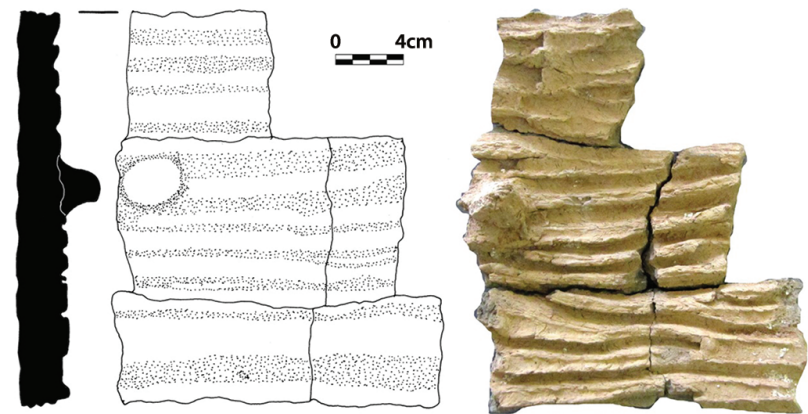

Fig. 16. Early Chalcolithic husking trays at Tepe Gheshlagh. 
there was signicifact change in the younger layers, i.e. layers III and IV. After initial settlement in the Middle Chalcolithic period, the deposits then show the remains of the Godin VII phase, which is an indication of the Late Chalcolithic period in eastcentral Zagros. In this regard, and due to the lack of evidence of any Pisdeli and Seh Gabi pottery styles in this phase, there seems to have been a cultural stasis, which fits with
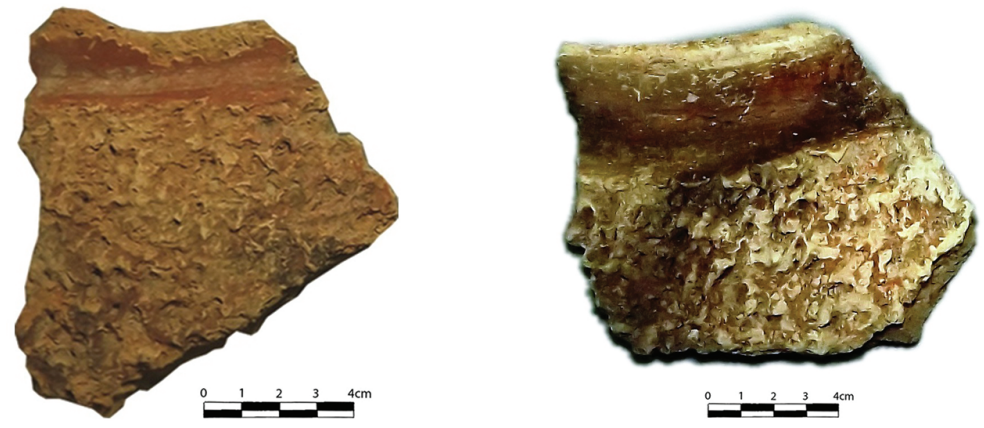

Fig. 17. Early Chalcolithic impressed pottery at Tepe Gheshlagh.

the cultural evidence of Pisdeli in the southwest and Seh Gabi and Hossain Abad in western Iran. The Tepe Gheshlagh archaeological finds show a continuity of Dalma culture in a relatively enclosed area between the valleys of east-central Zagros that lasted a longer period than in the peripheral area which can be due to the more suitable environment. It seems that the area around Tepe Gheshlagh did not face the same dificulties as were documented at Dalma Tepe and Tepe Seh Gabi that resulted in their respective cultural changes.

Considering the density and number of ceramic finds from the Chalcolithic period, it seems that the Dalma pottery tradition was long-lived in Western Iran
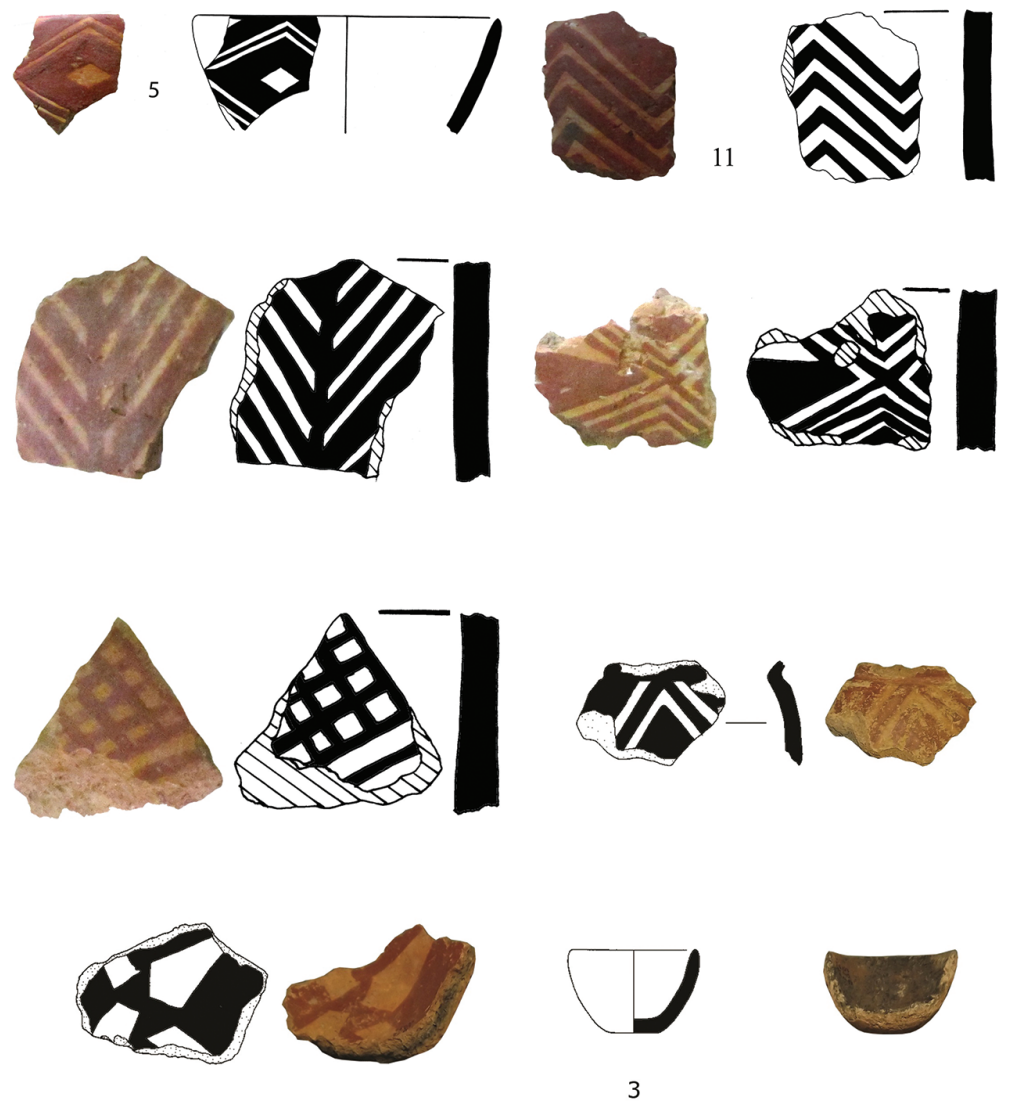

Fig. 18. Early Chalcolithic Dalma pottery from Tepe Gheshlagh.

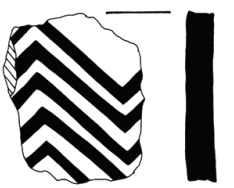

area. The presence of pottery traditions throughout Zagros, such as Seh Gabi and Dalma pottery in the northwest, as well as Haji Firuz traditions and the influence of the Hassuna culture from north Mesopotamia, clearly shows a connection between Tepe Gheshlagh and the neighbouring areas in the timespan from the $3^{\text {rd }}$ to $5^{\text {th }}$ millenium BC. Therefore, considering all these results, one can suggest the existence of transregional relations at this site.

It should be mentioned that the hypothesis of sudden growth in the Chalcolithic period in Zagros has already been proposed by several archaeologists (Henrickson 1983; 1985; Young, Levine 1974). Two important issues in this regard are the environmental and human factors.

Regarding the environmental factor, the area was occupied continuously over one thousand years, indicating the relatively stable environment and climate, and around $3500 \mathrm{BC}$ this situation gradually reached a point which looked very much like the current one. During this period, there was a gradual rise in temperature, the development of dense oak forests and a gradual increase in rainfall (Van Zeist et al. 1983). All these conditions increased the chances of population growth and made it possible for people to further exploitat the environment.

Regarding population factors, there is no doubt that from the beginning of the Chalcolithic period, the population of the Talvar River valley and Bijar suddenly increased; however, there have been no reports of Palaeolithic to 
Neolithic settlements in this area. The relative elevation above $1600 \mathrm{~m}$ and a colder climate be the main factor in the absence of settlements from these periods. Accordingly, it seems that at the end of the $6^{\text {th }}$ millennium BC, a large mass of people suddenly dispersed throughout the entire region. Traces of such rapid population growth and expansion can be seen in surveys of the Bijar plain and the Talvar River Basin. In fact, the increasing population required more space and access to resources, resulting in the distribution of the population. These sites were formed in a linear fashion on small plains between mountains. All of this confirms the hypothesis of a rapid occupation of the Zagros high valley in the late Neolithic in the 6th millennium BC. Due to the close resemblance of the pottery asseblages and architecture at the sites in the south Lake Uremia area, it appears that in the Neolithic the occupation extend-
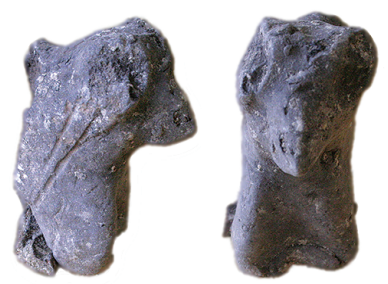

7
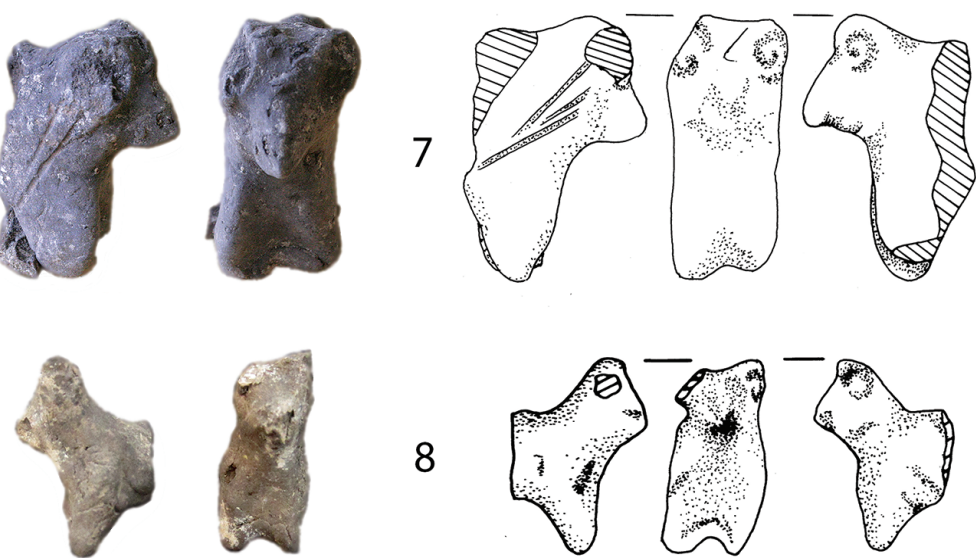

8
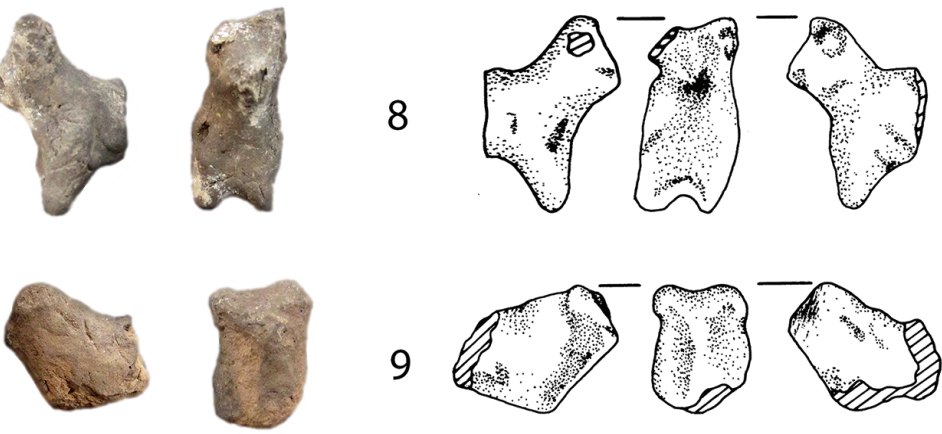

9
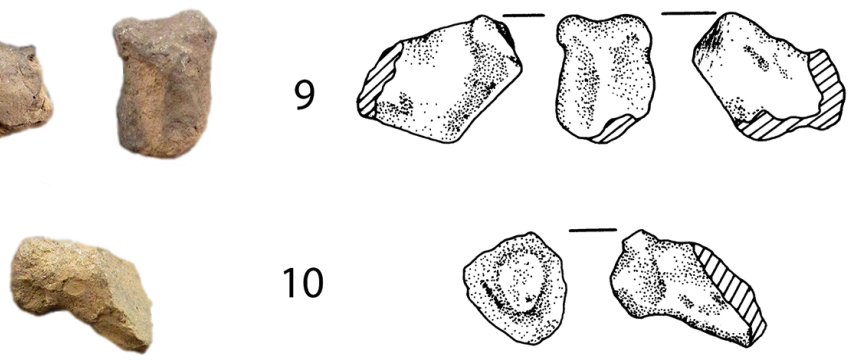

10
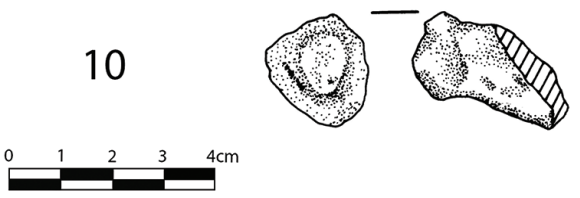

Fig. 19. Animal figurines of the Late Chalcolithic from Tepe Gheshlagh. ed from the Lake Uremia to the south as well as to the north Zagros area which coincides with the gradual warming of the climate. These populations took advantage of the more suitable natural conditions and settled in these areas for the first time, while they still maintained some cultural traditions, such as the making of bone tools and husking trays. More surprisingly, the way of life was still based on hunting and farming in less populated areas.

Archaeological excavations in Tepe Gheshlagh have offered significant information about Dalma culture in east Kurdistan which enables us to make a comprehensive analysis of cultural advances in this period compared to other sites. One reason for the importance of Tepe Gheshlagh in the Early Chalcolithic period is the 9-metre-thick layer containing Dalma pottery. It evidences permanent habitation, and no changes in materiality. This has not been seen in other parts of Iran or outside its borders. Due to this longevity, this area is one of the key sites for the study of Dalma culture.

A stable environment was reflected in the use of too much stucco to plaster warehouses and house floors, which in turn, remained the special characteristic of this culture. Also, the use of stucco as a material for consolidation within the context of architecture is considered a local phenomenon. Hence it is worth noting the following fundamental factors studied at Tepe Gheshlagh:

(1) The adaptation of architecture to the environment. Houses are made of thick mudbrick walls facing south, while winter winds blow from the west.

(2) Use of local material such as gypsum in building material, barn floors, wall coatings, and storage jar consolidation on the floor. The architectural patterns of the Chalcolithic period were influenced by the enironment, with gypsum being the main raw material. The use of pumice stone was another cultural feature of Tepe Gheshlagh buildings.

(3) Environmental adaptation such as the economic practises of hunting and fishing, animal husbandry, and also limited cultivation, as only a few sickle blades have been found in theses areas.

(4) The widespread use of local resources is evident at Tepe Gheshlagh. Not only large, but also small animals, such as rabbits, foxes, pigs, turtles, and fish were hunted, as demonstarted by the abundant remains of fish and turtle bones. The remnants of wild animal bones obtained from waste pits also indicate the hunting of these animals. 
As Tepe Gheshlagh is located in the centre of a natural corridor which connects the North West, the Central Plateau, and the western areas of Iran, we can expect regional and trans-regional connections. The special continental and environmental conditions of this region are undoubtedly similar to the neighbouring regions, such as the basin of Lake Urmia in the North West, the highlands of Zagros, and the north of Mesopotamia. Therefore, during the investigation of cultural data, the mutual effects of known and concurrent cultures, such as the Dalma and Middle-Dalma Chalcolithic cultures, and Seh Gabi, and also the Hassuna culture in the North of Mesopotamia, could be observed.

Relations with southern Mesopotamia can be seen through the study of cultural material, examples of which would be two pieces of pottery from the Ubaid and Umm Dabaghiyah tradition. A large amount of the Dalma pottery cultural material in a $9 \mathrm{~m}$ thick layer at Tepe Gheshlagh could point to the formation of the dominant culture among all those neighbouring areas. Considering the prevalence of Dalma culture in this layer, we can assume that Tepe Gheshlagh was one of the main centres of settlement and transition in this culture, from which other cultures in the vicinity were derived. It appears that during the Chalcolithic period, the population found this place suitable for animal husbandry, as well as slme limited cultivation. It also seems that the inhabitants

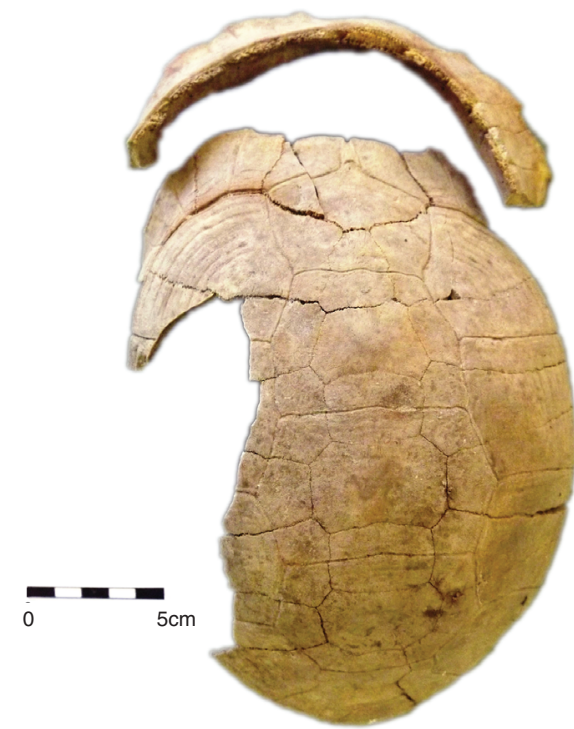

Fig. 20. Turtle shell found at the site.

of Dalma were already familiar with the Hassuna culture, and their main reason for immigration was to access more space, as well as population growth, forcing them to move towards the foothills and plains between the mountains. The steppe nature of the area made animal husbandry possible, since water was always accessible, although it is difficult to control and direct the rivers in these highlands. Directing water to farmland was especially hard, so animal husbandry was preferred, and water was not used for larger scale irrigation.

\section{$\therefore$}

\section{References}

Braidwood L., Braidwood R., Charles R., and Patty W. 1983. Prehistoric archaeology along the Zagros flanks. University of Chicago Oriental Institute Publication 105. Chicago.

Fazeli Nashli H., Valipour H., and Azizi Kharanaghi M. 2013. The Late Chalcolithic and Early Bronze Age in the Qazvin and Tehran Plains: a chronological perspective. In C. A. Petrie (ed.), Ancient Iran and its neighbors: Local developments and long-range interactions in the fourth millennium BC. Oxbow Books. 0xford: 107-130.

Hamlin C. 1975. Dalma Tepe, Iran. Journal of the British Institute of Persian Studies 13: 111-127.

Henrickson E. F. 1983. Ceramic Styles and cultural Interaction in the Early and Middle chalcolithic of central Zagros, Iran. Unpublished PhD dissertation. Department of Anthropology. University of Toronto University. Ann Arbor.
1985. An updated Chronology of the Early and Middle Chalcolithic of the Central Zagros Highlands, Western Iran. Iran 23: 63-108.

Henrickson E. F., Vitali V. 1987. The Dalma tradition: prehistoric Interregional cultural Integration in Highland western Iran. Paléorient 13(2): 36-45.

Lloyd S., Safar F., and Braidwood R. J. 1945. Tell Hassuna Excavations by the Iraq Government Directorate General of Antiquities in 1943 and 1944. Journal of Near Eastern Studies 4(4): 255-289.

Levine L. D., McDonald M. A. 1977. The Neolithic and Chalcolithic Period in the Mahidasht. Iran. Journal of the British Institute of Persian Studies 15: 39-50.

Levine L. D., Young T. C. 1986. A summary of the ceramic assemblages of the central western Zagros from the middle Neolithic to the late third millennium B.C. In Préhi- 
stoire de la Mésopotamie. Editions du Centre national de la recherche scientifique. Paris: 15-53.

Matthews R., Fazeli Nashli H. 2013. The Neolithisation of Iran. The Formation of New Societies. Oxbow books. Oxford.

McDonald M. 1979. An Examination of Mid-Holocene settlements patterns in the Central Zagros, Region of Western Iran. Unpublished PhD thesis. Department of Anthropology. University of Toronto. Toronto.

Merpert N. Y. A., Munchaev R. M. 1973. Early Agricultural Settlements in the Sinjar Plain, Northern Iraq Author. Iraq 35(2): 93-113.

Miller N. F. 2011. An Archaeobotanical Perspective on Environment, Plant Use, Agriculture, and Interregional Contact in South and Western Iran. Iranian Journal of Archaeological Studies 1: 1-8.

Mohamadifar Y. 2010. The first season excavation of Rezaabad Tepe. Iranian center for Archaeology research. Teheran.

Motarjem A. 2011. The first season excavation of Gheshlagh Tepe. Iranian center for Archaeology research. Teheran.

Motarjem A., Sharifi M. 2014. The Cultural Development of Chalcolithic era in the East of Central Zagros based on Archaeological Excavations at Tepe Gheshlagh in Bijar, Kurdistan Province. Iranian Journal of Archaeological Studies 4(1): 49-65.

2015. An Analysis on the Function and Nature of the Tokens and Clay Figurines from Tape Geshlagh of Talvar During the Chalcolithic Period. Pazhohesh-hay Bastan shenasi 4(7): 27-46.

Motarjem A., Heidari A. 2016. A Study of Chalcolithic Potteries Porosity to Evaluation of Social Complexity Based on Pottery Production in Tepe Gheshlagh Bijar. Journal of Iran's Pre-Islamic Archaeological Essays: 51-59.

Mohamadifar Y., Motarjem A. 2009. Tepe Pissa new Investigation at a Kura-Araxes site in central western Iran. $A n$ tiquity 83(320): 1-3.
Pollard M. A., Davoudi H., Mostafapour I., Valipour H. A., and Fazeli Nashli H. 2012. A New Radiocarbon Chronology for the Late Neolithic to Iron Age in the Qazvin Plain, Iran. Internatonal Journal of Humanities 19 (3): 1-41.

Rothman M., Badler V. 2011. Chapter 4. Contact and development in Godin VI. In H. Gopnik Hilary, M. Rothman (eds.), On the High Road: The History of Godin Tepe, Iran. The Royal Ontario Museum. Toronto: 67-137.

Saed A. 2010. The first season excavation Tepe Kolnan. University of Teheran. Unpublished PhD thesis. Teheran.

Tekin H. 2007. Hakemi Use: Güneydoğu Anadolu'da Yeni Bir Geç Neolitik Merkez. In M. Özdoğan, N. Başgelen (eds.), Türkiye'de Neolitik Dönem, Anadolu'da Uygarlı̆̆n Doğuşu ve Avrupa'ya Yaynlım. Yeni Kazllar-Yeni Bulgular. Arkeoloji ve Sanat Yayınları. Istanbul: 47-65.

Stein G. 1998. Southeast Anatolia before the Uruk expansion: preliminary report on the 1997 excavations at Hacinebi, Turkey. Anatolica 24: 143-193.

Swiny S. 1975. Survey in Northwest Iran, 1971. East and West 25(1-2): 77-96.

Voigt M. M. 1983. Hajii Firuz Tepe, Iran. The Neolithic settlement. Hasanlu excavation reports vol. 1. University of Pennsylvania. Philadelphia.

Yildrim B, Gates M. H. 2007. Archaeology in Turkey. American Journal of Archaeology 111(2): 275-356.

Young T. C. Jr. 1969. Excavations at Godin Tepe. First progress report. Occasional Papers no. 17. Art and Archaeology. Royal Ontario Museum. Toronto.

1975. An Archaeological survey of the Kangavar valley. Proceeding of the $3^{\text {rd }}$ Annual symposium on Archa eological Research in Iran 3: 23-30.

Young T. C., Levine L. 1974. Excavation of the Godin Project: Second progress report. Occasional Papers 26. Art and Archaeology. Royal Ontario Museum. Toronto.

\section{back to contents}

